\title{
Identifikasi Jenis Pigmen Dan Uji Potensi Antioksidan Ekstrak Pigmen Bakteri Serratia marcescens Hasil Isolasi Dari Sedimen Sumber Air Panas Gedong Songo
}

\author{
Adhitya Naufal, Endang Kusdiyantini dan Budi Raharjo \\ Departemen Biologi, Fakultas Sains dan Matematika, Universitas Diponegoro \\ Jl. Prof Soedharto, SH, Tembalang, Semarang 50275 \\ adhityanaufal7@gmail.com
}

\begin{abstract}
Pigments can be produced by plants, animals, and microbes, including the bacteria Serratia marcescens. Pigments are believed to be used as antibacterial, anticancer, antibiotic and antioxidant. The quality of the pigment is greatly determined by its type. The aim of this study was to identify the type of pigment produced by $\mathrm{S}$. marcescens resulting from the sediment of Gedong Songo hot spring, and testing its antioxidant activity. S. marcescens was grown on Nutrient Broth (NB) medium for 96 hours at room temperature and sampled once every 6 hours for growth measurement and pigment measurement. Cell dry weight was used to measure the growth of S. marcescens, while the measurement of pigment production was done using spectrophotometer with $535 \mathrm{~nm}$ wavelength for red pigment and identification of pigment with Thin Layer Chromatography and UV-Vis and testing of antioxidant activity using carotene bleaching method. The results showed the measurement of pigment production has optimal point at 48 hours at $1,319 \mathrm{mg} / \mathrm{L}$. Identification of pigment type $\mathrm{S}$. marcescens using TLC obtained value of $\mathrm{R}_{\mathrm{f}} 0,8$ with spectrophotometer wavelength at $536 \mathrm{~nm}$. The value of antioxidant activity Pigment S. marcescens obtained at $13 \%$.
\end{abstract}

Keywords: Serratia marcescens, prodigiosin, KLT, antioxidant

\begin{abstract}
Abstrak
Pigmen dapat dihasilkan oleh tumbuhan, hewan dan mikrobia, termasuk bakteri Serratia marcescens. Pigmen diyakini dapat digunakan sebagai antibakteri, antikanker, antibiotik dan antioksidan. Kualitas pigmen sangat ditentukan oleh jenisnya. Tujuan penelitian ini adalah identifikasi jenis pigmen yang diproduksi oleh S. marcescens hasil isolasi sedimen sumber air panas Gedong Songo, dan uji aktivitas antioksidannya. S. marcescens ditumbuhkan pada media Nutrient Broth (NB) selama 96 jam pada temperatur ruang dan tiap 6 jam sekali dilakukan pengambilan sampel untuk pengukuran pertumbuhan dan pengukuran pigmennya. Pengukuran pertumbuhan $S$. marcescens menggunakan berat kering sel, sedangkan pengukuran produksi pigmennya dilakukan menggunakan spektrofotometer dengan panjang gelombang $535 \mathrm{~nm}$ untuk pigmen merah serta identifikasi pigmen dengan Kromatografi Lapis Tipis (KLT) dan UV-Vis dan pengujian aktivitas antioksidannya menggunakan metode carotene bleaching. Hasil menunjukkan pengukuran produksi pigmen memiliki titik optimal pada jam ke 48 sebesar 1,319 mg/L. Identifikasi jenis pigmen $S$. marcescens menggunakan KLT didapatkan nilai $R_{f} 0,8$ dengan panjang gelombang pada spektrofotometer sebesar $536 \mathrm{~nm}$. Nilai aktivitas antioksidannya Pigmen S. marcescens didapatkan sebesar 13\%.
\end{abstract}

Kata Kunci: Serratia marcescens, prodigiosin, KLT, antioksidan

\section{PENDAHULUAN}

Pigmen adalah zat perwarna yang diproduksi oleh organisme hidup ataupun reagen kimia. Sejarah penggunaan pigmen kembali ke lukisan yang terdapat di gua prasejarah, yang memberikan bukti penggunaan oker, hematit, bijih besi coklat dan pigmen berbasis mineral lainnya lebih dari 30.000 tahun yang lalu. Dalam bidang seni penggunaan pigmen tanaman dan hewan untuk memperluas spektral pewarna anorganik yang tersedia dengan pilihan warna yang lebih meluas telah ada sejak ribuan tahun yang lalu. Cara yang paling tepat dalam pengklasifikasian pigmen menurut sumbernya, yaitu pigmen biologi (alami) dan pigmen sintesis. Pigmen sintesis dibagi menjadi 
dua kelompok yaitu pigmen organik dan anorganik (Daniel, 1986).

Pigmen alami yang sering dijumpai selain klorofil adalah karotenoid, dimana kartenoid ini terbagi menjadi dua kelas utama yaitu xantofil dan karoten yang sangat bermanfaat bagi kesehatan manusia meliputi provitamin A, antioksidan, antikanker dan meningkatkan respon imunitas. Karotenid merupakan pigmen yang berwarna kuning, orange hingga merah dapat ditemukan di makhluk hidup mulai dari manusia, hewan, tumbuhan, buah, alga, jamur maupun bakteri (Arlita, 2013)

Antioksidan merupakan senyawa yang mendonorkan elektron dengan berat molekul kecil yang mampu menghambat proses oksidasi dengan mengikat radikal bebas. Antioksidan dibagi menjadi dua berdasarkan sumbernya yaitu antioksidan endogen dan antioksidan eksogen. Antioksidan endogen merupakan antioksidan yang dapat diproduksi didalah tubuh secara alami. Contoh dari antioksidan endogen adalah enzim seperti superoksida dismutase, glutation peroksidase, glutation peroksidase, biliverdin reduktase, katalase, tioredoksin reduktase dan heme oksigenase. Selain enzim terdapat antioksida non enzim yaitu glutation dan koenzim-Q. Antioksidan eksogen adalah antioksidan yang tidak diproduksi didalam tubuh atau berasal dari makanan (Chunhuan et al, 2010).

$S$. marcescens berbentuk batang. Mikroorganisme ini termasuk dalam anaerob fakultatif, dimana dapat umbuh baik dalam kondisi terdapat oksigen ataupun tanpa adanya oksigen. $S$. marcescens merupakan bakteri gram negatif yang memiliki dinding sel tipis yang terbuat dari satu lapisan peptidoglikan yang tertutup oleh membran luar. Membran luarnya memiliki lipopolisakarida, yaitu fosfolipid yang terdiri dari asam lemak melekat pada dimer glukosamin fosfat (Slonczewski and Foster, 2009).

Identifikasi pigmen dapat dilakukan dengan kromatografi lapis tipis (KLT). Menurut Bintang (2010), Pemisahan senyawa dengan menggunakan kromatografi lapis tipis dalam medium secara prinsip sama dengan kromatografi kertas, tetapi memiliki beberapa kelebihan, minyalnya berupa lebih banyak campuran medium dan senyawa yang dapat ditambahkan. Pemisahan dapat dilakukan dengan cara adsorpsi, pertukaran ion, kromatografi partisi atau filtrasi gel pada medium yang digunakan. Metode ini sangat cepat dengan membutuhkan waktu hanya 1 hari. Noda yang dihasilkan sangat rapat, sehingga dalam mendeteksi senyawa dalam konsentrasi rendah.

Carotene Bleaching memiliki prinsip metode berupa hilangnya warna kuning akibat dari reaksi karoten dengan radikal bebas yang dibentuk oleh oksidasi emulsi asam linoleat, kecepatan pemutihan dapat diperlambat dengan adanya antioksidan (Salamah dan Nurushoimah, 2014). Menurut Bintang (2010), menyatakan prinsip dari Carotene Bleaching terletak pada pemucatan warna emulsi sistem beta karoten dan asam oleat. BHT digunakan sebagai pembanding karena memiliki keefektifan sebagai antioksidan paling tinggi walaupun memiliki satu gugus hidroksi $(-\mathrm{OH})$ dan memiliki jumlah resonansi yang sama dengan eugenol, namun bersifat lebih non polar dibandingkan dengan senyawa lainnya karena adanya gugus alkil yang lebih tersubstitusi yaitu t-butil $\left(-\mathrm{C}\left(\mathrm{CH}_{3}\right)_{3}\right)$. Pemucatan warna dari sistem merupakan parameter terjadinya reaksi oksidasi. Semakin besar penurunan nilai absorbansinya, maka semakin tinggi tingkat oksidasi yang terjadi pada sistem tersebut.

Tujuan penelitian ini adalah identifikasi jenis pigmen yang diproduksi oleh $S$. marcescens hasil isolasi sedimen sumber air panas Gedong Songo, dan uji antioksidannya.

\section{BAHAN DAN METODE Mikroorganisme dan Kultur Medium}

Kultur murni $S$. marcescens diperoleh dari koleksi Laboratorium Bioteknologi FSM Universitas Diponegoro. Medium untuk peremajaan kultur ditumbuhkan pada media nutrien agar.

\section{Pembuatan Kultur Strater}

Isolat $S$. marcescens dari NA diinokulasikan sebanyak 1 ose bakteri ke dalam nutrien broth (NB), kemudian diinkubasi pada rotary shaker selama $\pm 12 \mathrm{jam}$, kecepatan $80 \mathrm{rpm}$ pada suhu $28^{\circ} \mathrm{C}$ sebagai digunakan sebagai kultur starter dengan kepadatan sel $10^{7} \mathrm{cfu} / \mathrm{ml}$ (Venil and Lakshmanaperumalsamy, 2009). 
Pertumbuhan Isolat Bakteri Serratia marcescens Setelah mencapai $10^{7} \mathrm{CFU} / \mathrm{ml}$ kemudian diambil sebanyak 5\% (v/v) starter dipindahkan ke $100 \mathrm{ml}$ kedalam medium NB dibuat perlakuan sebanyak 3 kali pengulangan dan diinkubasi pada rotary shaker selama 96 jam kecepatan $80 \mathrm{rpm}$ pada suhu $28^{\circ} \mathrm{C}$. Setiap 6 jam sekali dilakukan pengambilan sampel untuk diamati pertumbuhan sel. Kurva pertumbuhan dibuat dengan menghitung berat kering untuk mengukur konsentrasi pigmen seluler (Venil and Lakshmanaperumalsamy, 2009).

\section{Pengukuran Berat Kering Sel}

Sampel diambil sebanyak $1 \mathrm{ml}$ dimasukkan kedalam ependorf kemudian dilakukan sentrifugasi dengan kecepatan $3.000 \mathrm{rpm}$ selama 10 menit. Supernatan dan sel dipisahkan, kemudian sel dikeringkan menggunakan oven selama 15 jam pada suhu $80^{\circ} \mathrm{C}$. Tabung berisi sel diletakan pada desikator untuk memastikan supernatan tidak ada yang tersisa. Sel yang telah kering ditimbang sampai berat konstan. Berat kering sel diperoleh dari selisih ependorf yang berisi sel dengan ependorf kosong (Yuliana, 2008). Selanjutnya dibuat grafik untuk pengukuran pertumbuhan bakteri.

\section{Ekstraksi Pigmen dan Pengukuran Pigmen}

Kultur bakteri diambil $4 \mathrm{ml}$ dari medium pertumbuhan setiap 6 jam sekali pada inkubasi selama 96 jam, selanjutnya dilakukan pemisahan antara sel dari supernatannya menggunakan sentrifuse kecepatan $4.000 \mathrm{rpm}$ selama 25 menit. Pelet (sel) yang dihasilkan ditambah $4 \mathrm{ml}$ metanol dan di vortex, lalu disentrifugasi pada kecapatan $4.000 \mathrm{rpm}$ selama 25 menit untuk mendapatkan pigmennya. Pigmen diukur dengan menggunakan spektrofotometer pada panjang gelombang $535 \mathrm{~nm}$ (Venil and Lakshmanaperumalsamy, 2009). Hasil nilai absorbansi akan digunakan untuk pengukuran total pigmennya.

Pengukuran total pigmennya menurut Mahmoud et al (2015), ditentukan dengan dengan formulasi sebagai berikut :

$$
\begin{array}{ll}
\operatorname{TP}(\mathrm{mg} / \mathrm{L}) & =\frac{\mathrm{OD} \times 323,4 \times \mathrm{df} \times 10^{3}}{7.07 \times 10^{4}} \\
\text { Keterangan: } & =\text { absorbansi pada } 535 \mathrm{~nm} \\
\mathrm{OD} & =\text { koefisen ekstensi } \\
7.07 \times 10^{4} & =\text { faktor pengenceran } \\
\mathrm{df} & =\text { konversi satuan dari }(\mathrm{g} / \mathrm{L}) \mathrm{ke}(\mathrm{mg} / \mathrm{L}) \\
10^{3} & =\text { berat molekul pigmen merah }
\end{array}
$$

\section{Identifikasi Pigmen Serratia marcescens}

Identifikasi pigmen menggunakan kromatografi lapis tipis dan analisa panjang gelombang dengan spektrofotometer. Langkah awal yang harus dilakukan dalam kromatografi Lapis Tipis disediakan pelat silika gel, setelah itu pembuatan kromatgram bagian bawah dan bagian atas pelat dibuat garis horizontal dengan jarak $1 \mathrm{~cm}$ dari ujung bawah dan $0,5 \mathrm{~cm}$ dari ujung atas. Pada garis awal dibuat spot dan ditotalkan larutan pigmen yang akan danalisis menggunakan pipet kapiler. Pelat kemudian dimasukkan ke dalam bejana yang berisi eluen. Eluen yang digunakan adalah kloroform: metanol $(9,5: 0,5)$ (Vora et al, 2014). Setelah eluen naik sampai batas yang ditetapkan, pelat silika diangkat dari bejana, spotspot yang terlihat ditentukan nilai $\mathrm{R}_{\mathrm{f}}$.

Menurut Rosang dan Billy (2016), perhitungannya adalah sebagai berikut:

$$
\mathrm{R}_{\mathrm{f}}=\frac{\text { Jarak antara titik awal dan pusat spot yang dihasilkan }}{\text { Jarak antara titik awal dengan jarak yang ditempuh pengembang }}
$$

Spektrofotometer UV-Vis digunakan untuk konfirmasi hasil dari ekstrak pigmen pada KLT untuk diukur nilai absorbansinya. Masing-masing spot yang terdapat pada silika gel dilarutkan dengan menggunakan $4 \mathrm{ml}$ metanol, selanjutnya dianalisa dengan spektrofotometer UV-Vis. Nilai absorbansi pada panjang gelombang tertentu menunjukan jenis pigmen. Hasil yang diperoleh nantinya akan dibandingkan dengan panjang gelombang dari referensi 


\section{Uji Aktivitas Antioksidan Metode Cartene Bleaching}

Tahap ini diawali dengan pembuatan sistem emulsi asam linoleat-beta karoten yaitu sebanyak $5 \mathrm{ml} \quad \beta$-karotene $\quad(0,2 \quad \mathrm{mg} / \mathrm{ml} \quad$ kloroform $)$ ditambahkan ke dalam labu evaporasi berisi $0,1 \mathrm{ml}$ asam linoleat $0,02 \mathrm{M}$ dan $1 \mathrm{ml}$ Tween 80 . Kloroform diuapkan dari campuran dengan suhu $45^{\circ} \mathrm{C}$, kemudian ditambahkan $250 \mathrm{ml}$ aquades, lalu dikocok hingga membentuk emulsi (Bintang, 2010). Sistem emulsi yang telah dibuat sebanyak $250 \mathrm{ml}$, kemudian dibagi menjadi 5 dengan masingmasing volume $50 \mathrm{ml}$ pada gelas erlenmeyer. Sebanyak $2 \mathrm{ml}$ sampel $0,5 \%(\mathrm{v} / \mathrm{v})$ diberikan ke masing masing sistem emulsi asam linoleat-beta karoten dengan kontrol negatifnya adalah etanol, kontrol positif BHT dan sampel pigmen $S$. marcescens kemudian ditempatkan pada penangas air pada suhu $65^{\circ} \mathrm{C}$ selama 120 menit. Absorban diukur setiap 15 menit pada panjang gelombang $470 \mathrm{~nm}$ (Bintang 2010).

Menurut Salamah dan Nurushoimah (2014), nilai aktivitas antioksidannya dapat dihitung dengan rumus seperti berikut :

$$
A A=100\left[1-\left(\frac{A_{o}-A_{t}}{A_{o}^{0}-A_{t}^{0}}\right)\right]
$$

Dimana $A A$ adalah aktivitas antioksidan, $A_{t}$ dan $A_{t}{ }^{0}$ nilai absorbansi yang terukur pada waktu 120 menit inkubasi sampel \& control $A_{0}$ dan $A_{0}{ }^{0}$ nilai absorbansi yang terukur pada waktu ke nol inkubasi sampel dan kontrol.

\section{HASIL DAN PEMBAHASAN \\ Pertumbuhan $S$. marcescens}

Pertumbuhan merupakan pertambahan jumlah sel dan massa sel. Pertumbuhan dapat diukur berdasarkan berat kering sel. Media yang digunakan untuk pertumbuhan $S$. marcescens berupa nutient broth (NB) dan suhu yang digunakan $28^{\circ} \mathrm{C}$. Menurut Shahitha and Poornima (2012), kondisi optimal untuk pertumbuhan dan produksi pigmen $S$. marcescens dengan media NB pada suhu $28^{\circ} \mathrm{C}$ dan $\mathrm{pH}$ 7. Penelitian ini diawali dengan membuat starter dengan umur 12 jam, yang diukur absorbansinya mencapai 1.165 pada panjang gelombang $600 \mathrm{~nm}$. Starter tersebut sudah dapat dipindahkan ke medium pertumbuhan sebanyak 5\% (v/v). Pengukuran pertumbuhan $S$. marcescens ini menggunakan berat kering sel yang dilakukan dengan pengambilan sampel setiap 6 jam sekali selama inkubasi 96 jam melalui shaker dengan kecepatan 75 rpm. Menurut Manzila dkk., (2014), untuk pertumbuhan dan produksi pigmen $S$. marcescens, bakteri diinkubasi melalui inkubator bergoyang dengan kecepatan 75 rpm selama 4 hari.

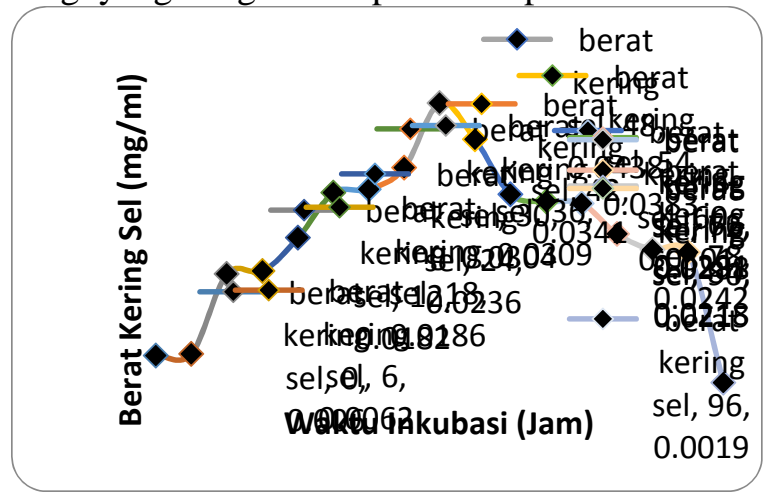

Gambar 1. Kurva pertumbuhan S. marcescens berdasarkan berat kering sel selama inkubasi 96 jam.

Kurva pertumbuhan S. marcescens (Gambar 1) menunjukkan fase lag, fase logaritmik, fase stasioner dan fase kematian. Medium yang digunakan starter sama dengan medium pertumbuhan yaitu dengan NB, namun masih terdapat fase lag dikarenakan pemindahan bakteri dari medium dengan volume yang kecil ke medium yang lebih besar. Fase lag dimulai dari jam ke 0 hingga ke jam 6 , fase lag tidak terlalu lama disebabkan medium starter dan medium pertumbuhan yang digunakan sama sehingga fase lag sebagian sudah terjadi di starter.

Fase logaritmik awal dimulai dari jam ke 6 hingga ke jam 36, pada jam 36 merupakan fase logaritmik akhir dan dimana keberadaan jumlah selnya mencapai $0,0309 \mathrm{mg} / \mathrm{ml}$. Sedangkan fase stasioner dimulai dari jam ke 42 sampai jam ke 60 dimana terjadinya kenaikan kemudian diikuti dengan penurunan, hal tersebut disebabkan jumlah sel yang tinggi menyebabkan terjadinya kompetisi untuk memperoleh nutirsi yang semakin berkurang pada medium pertumbuhan. Fase stasioner diakhiri pada jam ke 60 dan memasuki fase kematian pada 
jam ke 66 dimana terjadinya penurunan yang cukup pesat sampai pada jam ke 96 dengan jumlah sel sebesar $0,0019 \mathrm{mg} / \mathrm{ml}$.

Menurut Madigan et al (2012), pertumbuhan mikrobia melalui beberapa fase diantaranya; (1). Fase lag adalah dimana mikroba baru menyesuaikan diri dengan kondisi lingkungan sekitar; (2). Fase log adalah dimana sel mikrobia membelah dengan capat dan konstan sehingga jumlah selnya meningkat dari sebelumnya; (3). Fase stasioner adalah fase dimana jumlah peningkatan sel mikrobia sama dengan jumlah kematian sel sehingga keberadaan ini menyebabkan kurva berjalan dengan seimbang tidak ada terjadinya penaikan maupun penurunan; (4). Fase kematian adalah fase dimana terjadinya kematian sel bakteri dalam jumlah yang besar akibat terjadinya kekurangan jumlah nutrisi pada medium.

\section{Produksi pigmen $S$. marcescens}

Pertumbuhan $S$. marcescens menghasilkan metabolit sekunder, salah satunya adalah pigmen. Pigmen merupakan suatu zat pewarna yang dihasilkan oleh mikroorganisme hidup. Pigmen yang diproduksi oleh bakteri akan dihasilkan ketika memasuki fase stasioner pada pertumbuhan bakteri. $S$. marcescens termasuk dalam mikroorganisme anaerob fakultatif, dimana bakteri ini mampu tumbuh dengan adanya oksigen maupun tanpa oksigen. Tahap awal dari pertumbuhan bakteri akan memanfaatkan sumber karbonnya untuk metabolit primernya. Setelah melewati fase pertumbuhan bakteri, metabolit sekunder akan diproduksi atau pada fase stasioner awal. Metabolit sekunder seperti pigmen tidak mendukung pertumbuhan dari bakteri dan produksinya sangat dipengaruhi oleh faktor lingkungan. Hasil dari produksi pigmen pada $S$. marcescens ditunjukkan pada Gambar 2.

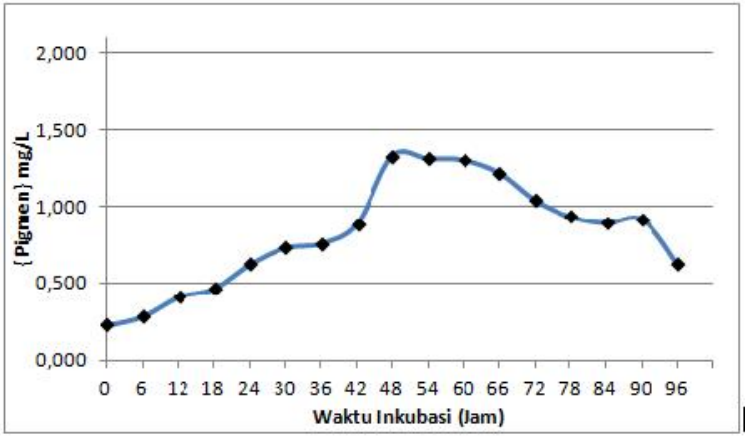

Gambar 2. Produksi pigmen merah S. marcescens dari jam ke 0 sampai jam ke 96

Hasil pengukuran pigmen merah yang diambil tiap 6 jam sekali untuk diukur nilai absorbansinya terjadi peningkatan dari jam ke 0 hingga jam ke 48. Menurut Irdawati (2010), kadar pigmen akan terus meningkat dengan berjalanannya waktu fermentasi namun hanya sampai pada waktu fermentasi tertentu. Pigmen merah sebesar 1,319 $\mathrm{mg} / \mathrm{L}$ merupakan titik optimal pada jam 48 pertumbuhan S. marcescens (Gambar 2), hasil penelitian masih rendah dibandingkan dengan menurut Phatake and Dharmadhikari (2015), produksi pigmen $S$. marcescens tertinggi sebesar $1455 \mathrm{mg} / \mathrm{L}$ pada waktu inkubasi jam ke 72 . Penurunan secara perlahan intensitas warna dari pigmen merah pada $S$. marcescens terjadi di waktu inkubasi 48-96 jam, hal tersebut dikarenakan jumlah selnya pada pertumbuhan juga mengalami penurunan karena kadar nutrisi yang semakin berkurang. Namun menurut Irdawati (2010), penurunan intensitas warna pigmen disebabkan karena perubahan-perubahan ikatan atau gugusgugus fungsionalnya, sehingga menjebabkan terjadinya kerusakan pada gugus kromofor pigmen

\section{Identifikasi Pigmen Merah S. marcesccens}

Identifikasi pigmen merah $S$. marcescens menggunakan kromatokrafi lapis tipis (KLT). KLT adalah suatu teknik untuk memisahkan beberapa senyawa dalam kurun waktu yang cepat dengan alat yang sederhana. Sebelum dilakukan identifikasi, kultur bakteri $S$. marcenscens disentrifugasi pada kecepatan $4.000 \mathrm{rpm}$ selama 25 menit dengan tujuan agar pelet berupa sel dan supernatan berupa NB dapat terpisah. Kemudian ditambah supernatan dibuang dan pelet ditambahkan dengan metanol 
sebanyak $4 \mathrm{ml}$. Selanjutnya di vortex selama 5 menit dengan dilanjutkan sentrifugasi selama 25 menit dengan kecepatan $4.000 \mathrm{rpm}$. Fungsi dari penambahan metanol berguna sebagai pemecah sel dengan pigmen. Menurut Phatake and Dharmadhikari (2015), untuk mengekstrak pigmen dari bakteri menggunakan metanol. Hasil sentrifugasi terbagi menjadi dua, yaitu supernatan dan pelet. Supernatan adalah hasil dari sentrifugasi dengan bobot jenis yang lebih rendah daripada pelet. Sedangkan pelet adalah hasil sentrifugasi dengan bobot jenis lebih tinggi daripada supernatan. Posisi pelet terletak dibagian dasar dari tabung sentrifugasi. Pelet dari hasil sentrifugasi tersebut adalah sel dan supernatannya berupa pigmen.

Supernatan berupa pigmen yang larut dalam metanol akan di identifikasi dengan menggunakan KLT, untuk mencari jenis pigmen yang terkandung pada bakteri $S$. marcescens. Plat KLT yang digunakan adalah Silica Gel $\mathrm{F}_{254}$. Eluen yang digunakan berupa kloroform : metanol dengan perbandingan 9,5:0,5. Menurut Vora et al (2014), untuk karakteristik pigmen yang terdapat pada bakteri $S$. marcescens dengan KLT menggunakan eluen berupa kloroform : metanol (95:5;5\% v/v). Hasil dari KLT yang diamati hanya terdapat 1 spot menggunakan eluen kloroform : metanol $=9,5: 0,5$ membutuhkan waktu 4 menit 37 detik untuk sampai garis batas atas. Hasil KLT ditunjukkan pada Gambar 3.
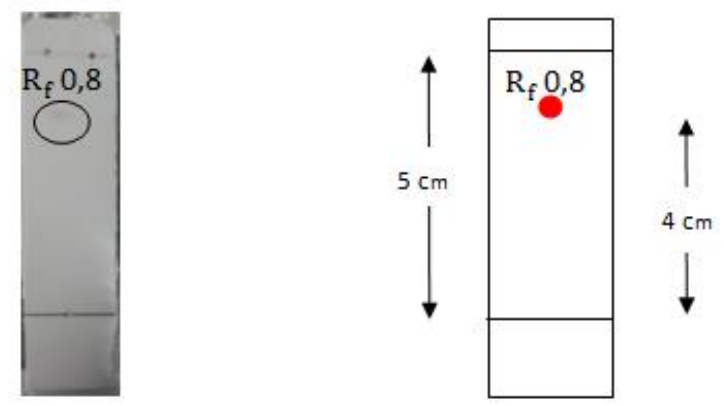

Gambar 3. Hasil KLT dari pigmen merah $S$. marcescens

Setelah dihitung dengan jarak pigmen (spot berwarna merah) dibagi dengan jarak tempuh eluen maka didapatkan nilai $\mathrm{R}_{\mathrm{f}}$ sebesar 0,80 . Menurut Vora et al (2014), setelah diidentifikasi melalui
KLT maka diperoleh nilai $\mathrm{R}_{\mathrm{f}}$ sebesar 0,8 yang merupakan pigmen prodigiosin, diperkuat dengan Pore et al (2016), didapatkan pada penelitian untuk pigmen merah prodigiosin pada bakteri $S$. marcescens didapatkan nilai $\mathrm{R}_{\mathrm{f}}$ 0,84. Setelah diidentifikasi melalui KLT selanjutnya pigmen prodigiosin didalam pelarut metanol dilakukan konfirmasi berdasarkan panjang gelombangnya menggunakan spektrofotometer UV-Vis. Menurut Vora et al (2014), pelarut pigmen prodigiosin menggunakan metanol dan berfungsi sebagai blanko dalam analisa spektrofotometer UV-Vis. Hasil dari konfirmasi dengan spektrofotometer UVVis didapatkan panjang gelombang $536 \mathrm{~nm}$. Menurut Song et al (2006), pigmen yang telah dilakukan identifikasi dengan KLT dilarutkan dalam metanol untuk dilanjutkan analisa menggunakan Spektofotometer UV-Vis untuk mengetahui panjang gelombang optimum yaitu 536 nm. Hal tersebut diperkuat dengan pendapat Casullo de Araujo et al (2010), Panjang gelombang optimun untuk pigmen prodigiosin pada Serratia marcescens sebesar $536 \mathrm{~nm}$ yang dapat dilihat pada Gambar 4.

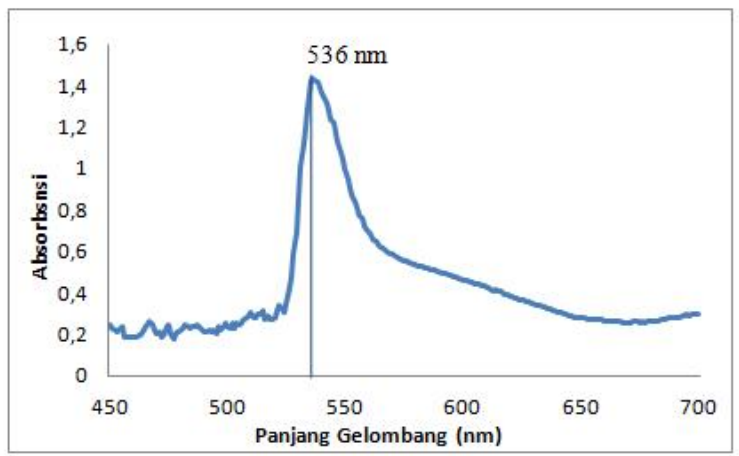

Gambar 4. Panjang gelombang optimum dari prodigiosin $S$. marcescens

\section{Uji Antioksidan Pigmen Merah serratia marcescens}

Uji antioksidan pada penelitian ini menggunakan metode Carotene Bleaching dengan prinsip pemucatan warna emulsi sistem beta karoten dan asam linoleat. Menurut Utami dkk (2009), metode Carotene Bleaching merupakan metode spektrofotometri berdasarkan kemampuan dari antioksidan untuk mencegah terjadinya peluruhan warna jingga yang disebabkan oleh 
oksidasi dalam sistem emulsi. Peluruhan warna jingga dapat ditunjukkan dengan penurunan absorbasi. Hal tersebut diperkuat dengan Salamah dan Nurushoimah (2014), prinsip dari metode ini adalah dengan warna jingga akan hilang akibat adanya reaksi dari beta karoten dengan radikal bebas yang terbentuk dari oksidasi emulsi asam linoleat, kecepatan penurunan dapat dilambatkan dengan hadirnya antioksidan.

Pengujian aktivitas antioksidan pigmen merah (prodigiosin) dari bakteri $S$. marcescens terlebih dahulu dengan pembuatan emulsi asam linoleat-beta karoten dengan menggunakan beta karoten seta campuran asam linoleat dan Tween-80. Beta karoten digunakan sebagai indikator aktivitas antioksidan (Utami dkk, 2009). Asam linoleat berfungsi sebagai asam lemak tak jenuh yang nantinya akan membentuk radikal bebas. Thomas (1985), dengan keberadaan lemak tak jenuh akan meningkatkan kereaktifannya terhadap oksidasi dengan adanya penambahan iktan rangkap pada rantai molekul. Tween-80 berfungsi sebagai emulsifier. Menurut Rowe (2009), bahwa Tween80 berfungsi semagai emulgator.

Sistem emulsi yang terbentuk dibagi menjadi 5 untuk perlakuan kontrol positif dengan menggunakan Butylated Hydroxytoluene (BHT), pigmen $S$. marcescens dengan 3 kali ulangan, dan kontrol negatif berupa etanol. Setelah itu akan diletakan pada penangas air pada suhu $65^{\circ} \mathrm{C}$ selama 120 menit, yang nantinya setiap 15 menit sekali diukur nilai absorbansinya pada panjang gelombang $470 \mathrm{~nm}$. Menurut Utami dkk (2009), rentang 400-500 $\mathrm{nm}$ merupakan panjang gelombang yang akan mampu diserap oleh karotenoid. Hasil dari pengujian aktivitas antioksidan pigmen $S$. marcescens setelah dilakukan perhitungan penurunan nilai absorbansi adalah sebesar 13\% dibandingkan dengan BHT yang merupakan kontrol positif sebesar 30\%, sehingga dapat disimpulkan bahwa pigmen tersebut memiliki aktvitas sebesar 13\%. BHT memiliki nilai yang lebih besar dibandingkan oleh pigmen disebabkan BHT merupakan antioksidan meupakan senyawa antioksidan sintetik. Menurut Aini dkk (2007), BHT memiliki satu gugus hidroksi $(-\mathrm{OH})$ namun kemampuan keefektifannya sebagai antioksidan tinggi. Hasil uji antioksidan dengan menggunakan metode Carotene Bleaching ditunjukkan dengan Gambar 5 dan Gambar 6.

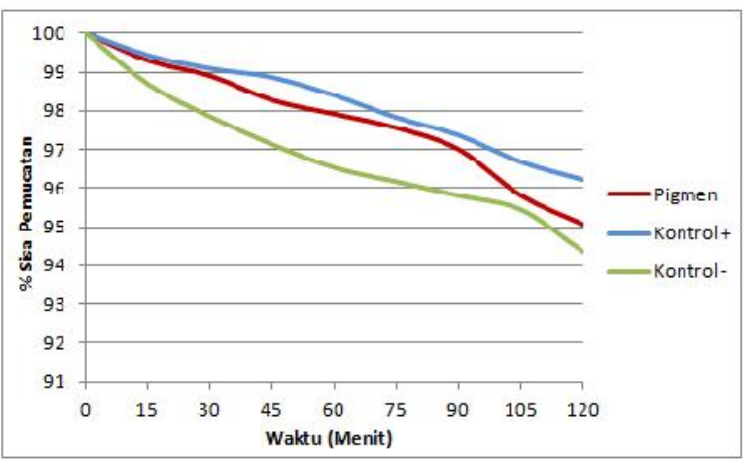

Gambar 5. Grafik sisa pemucatan beta karoten

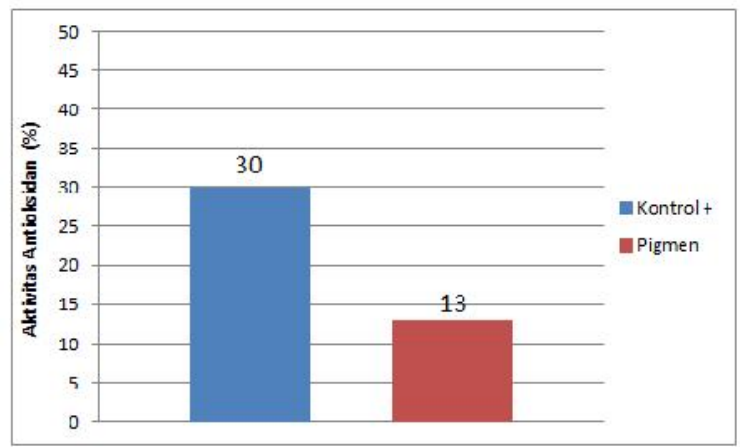

Gambar 6. Perbandingan aktiitas antioksidan (\%) antara kontrol positif dan pigmen.

Hasil dari penelitian ini mendapatkan pigmen yang merupakan sumber antioksidan dari bakteri $S$. marcescens yang telah diuji dengan menggunakan metode Carotene Bleaching. Antioksidan merupakan suatu senyawa dengan memiliki fungsi reaksi oksidasi akibat radikal bebas. Kondisi lingkungan yang kurang baik bagi tubuh seperti asap kendaraan, asap pabrik, merokok, makanan cepat saji, dan paparan sinar matahari dapat menyebabkan radikal bebas. Adanya radikal bebas didalam tubuh bila tubuh kekurangan zat antioksidan dapat menyebabkan berkembangan beberapa penyakit seperti kanker, jantung dan penyakit degeneratif lainnya. Maka dari itu tubuh memerlukan asupan tambahan dari luar yang dapat membantu dalam reaksi oksidasi tersebut contohnya adalah pigmen dari $S$. marcescens yang dapat dijadikan suplemen makan sebagai 
antioksidan. Sedangkan menurut Sarastani dkk (2002), salah satu cara efektif untuk mencegah kerusakan oksidatif dengan penggunaan antioksidan

\section{KESIMPULAN}

Hasil penelitian menunjukkan pengukuran pertumbuhan dan produksi pigmen oleh $S$. marcescens tertinggi pada jam ke 48 sebesar 1,319 $\mathrm{mg} / \mathrm{L}$. Pigmen yang telah diidentifikasi melalu metode KLT didapatkan jenis pigmen berupa prodigiosin dengan nilai $\mathrm{R}_{\mathrm{f}}$ sebesar 0,8 dan memiliki panjang gelombang $536 \mathrm{~nm}$ dengan analisa spektrofotometer. Kemampuan antioksidannya diuji dengan metode Carotene Bleaching didapatkan hasil sebesar $13 \%$.

\section{DAFTAR PUSTAKA}

Aini, N., Bambang P., dan Iqmal T. 2007. Structure-Antioxidant Activities Relationship Analysis of Isoeugenol, Eugenol, Vanilin and Their Derivates. Indo. J. Chem. 7(1): 61-66.

Arlita N.R., Ocky K.R., dan Adi S., 2013. Identifikasi Pigmen Karotenoid Pada Bakteri Simbion Rumput Laut Caulerpa Cupressoides (Vahl) C. Agardh, Journal Of Marine Research. 2(3): 68-77.

Bintang, M. 2010. Biokimia Teknik Penelitian. Erlangga, Jakarta.

Casullo de Araujo, H.W., Fukushima, K., and Campos, T.G.M. 2010. Prodigiosin Production by Serratia marcescens UPC 1549 Using Renewable-Resources as a Low Cost Substrate. Molecules. 15: 6931-6940.

Chunhuan H., Xiaowen J., Yingming P., Hengshan W., Kai, W., Min, L., and Lizhu, Y. 2010. Antioxidant Activity of Alcoholic Extract of Agrimonia pilosa Ledeb. Medical Chemistry Research. 19: 448-461.

Daniel, M.M. 1986. Handbook of U.S. Colorant for Food, Drugs, and Cosmetics. (2nd).: WileyInterscience publications, United State of America.

Irdawati. 2010. Pengaruh Jumlah Starter dan Waktu Fermentasi Terhadap Pigmen yang Dihasilkan oleh Monascus purpureus pada Limbah Ubi Kayu (Manihot utilisima). Eksata. 1: 19-24.
Madigan, M. T., John, M.T., and David, A.S. 2012. Brock biology of microorganisms13th ed. Pearson Education, Inc., Amerika.

Mahmoud, S.T., Khalid, J.K.L., and Reem, W.Y. 2015. Enchancement of Prodigiosin Production by Serratia marcescens S23 Via Introducing Microbial Elicitor Cells Into Culture Medium. Irai Journal of Science. 50(3): 1938-1951.

Manzila, I., Priyatno, T.P., Herlis., R., Rusmana, I., Samudra, I.M., dan Suryadi, Y. 2014. Pengaruh Media terhadap Produksi Prodigiosin Isolat Bakteri Entomopatogen Serratia marcescens Asal Wereng Batang Cokelat. Jurnal AgroBiogen. 10(2):77-84.

Phatake, Y.B., and Dharmadhikari, S.M. 2015. Studies On Production of Prodigiosin from Serratia marcescens and Statistical Optimization of Production Process by Using PBD. IJPRBS. 4(5): 146-159.

Pore, T.S., Ashwini, B.K. and Naiem, H.N. 2016. Production, Purification, Identification of Prodigiosin From Serratia sp. and Its Antimicrobial Activity. RJLBPCS. ISSN: 2454-6348.

Rosang, C. dan Billy T.W. 2016. Penentuan Kandungan Pigmen Klorofil pada Lamun Jenis Halophila ovalis di Perairan Malalayang. Jurnal Pesisir dan Laut Tropis. 1(1): 15-19.

Rowe, R.C., Sheskey, P.J., and Quinn, M.E. 2009. Handbook of Pharmaceutical Excipients. Pharmaceutical Press, Washington, DC.

Salamah, N., dan Nurushoimah. 2014. Uji aktivitas Antioksidan Ekstrak Etanol Herba Pegagagan (Centella asiatisca (L) Urb.) dengan Metode Penghambatan Degradasi Beta-Karoten. Farmasains. 2(4): 177-181.

Sarastani, Dewi, Soewarno T., Soekarto, T.R. Muchtadi, D.F., dan Anton A. 2002. Aktivitas Antioksidan Ekstrak dan Fraksinasi Ekstrak Biji Atung (Parinarium glaberrimum Hassk). Jurnal. Teknol. dan Industri Pangan. 13(2): 149-156.

Shahitha, S., and Poornima, K. 2012. Enhanced Production of Prodigisin Productin in Serratia Marcescens. Jurnal of Applied Pharmaceutical Science. 2(8): 138-140. 
Slonczewski, J. and Foster, J. 2009. Microbiology: An Evolving Science. W.W. Norton \& Company, Inc., New York.

Song, M.J.; Bae, J.; Lee, D.S.; Kim, C.H.; Kim, J.S.; Kim, S.W.; and Hong, S.I. 2006 Purification and Characterization of Prodigiosin Produced by Integrated Bioreactor from Serratia sp. KH-95. J. Biosci. Bioeng. 101: 157-161.

Thomas, H.W. 1985. Bailey's Industrial Oil and Fat Product, Volume 3: Jhon Wiley \& Son, New York.

Utami, T.S., Rita, A., Heri, H., dan Ahmad, R. 2009. Perbandingan Aktivitas Antioksidan Ekstrak Etanol Daun Simpur (Dillenia indica) dari Berbagai Metode Ekstraksi dengan Uji ANOVA. Fakultas Teknik Universitas Indonesia. Seminar Nasional Teknik Kimia Universitas Indonesia. ISBN: 987-99-98300-1-2.
Venil, C.K. and Lakshmanaperumalsamy, P. 2009. Application of Statistical Design to The Optimization of Culture Medium for Prodigiosin Production by Serratia marcescens. Malaysian Journal of Microbiology. 5(1): 55-61.

Vora, J.U., Jain, N.K., and Modi, H.A. 2014. Extraction Characteruzation and Application Studies of Red Pigment of Halophile Serratia marcescens KH1R KM035849 Isolated from Kharaghoda Soil. Int J. Pure App. Biosct. 2(6): 160-168.

Vora, J.U., Jain, N.K., and Modi, H.A. 2014. Extraction Characteruzation and Application Studies of Red Pigment of Halophile Serratia marcescens KH1R KM035849 Isolated from Kharaghoda Soil. Int J. Pure App. Biosct. 2(6): 160-168.

Yuliana, N. 2008. Kinetika Pertumbuhan Bakteri Asam Laktat Islat T5 yang Berasal dari Tempoyak. Jurnal Teknologi Industri dan Hasil Pertanian. 13(2): 108-116 